\title{
Detection of toxigenic Vibrio cholerae by PCR
}

\author{
الكثف عن بكتريا ضمات الكوليرا المنتجة للسموم باستخدام الـPCR \\ Majeed Arsheed Sabbah Bilal Kamil Sulaiman Kifah, A. Jasim* \\ Mohammod M. farhan \\ Biotechnology Research Center \\ *Alnahrain University / Central health laboratory / ministry of health \\ محمد محمود فرحان

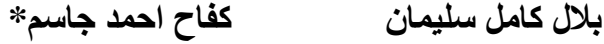
مركز بحوث التقنيات الاحيائية جامعة النهرين

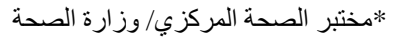

\begin{abstract}
OLholera toxin (CT) is a major virulence factor of $V$. cholerae causing water diarrhea. The detection of CT-producing $V$. cholerae using conventional culture-, biochemical- and immunological-based assays is time-consuming, laborious, and requiring more than three days perform. In this work a specific primers for $\operatorname{ctx} B$ gene were used for detection of $V$. cholera in water samples. Few colonies of $\boldsymbol{V}$. cholera were suspended in water and used as a template in PCR reaction for the detection of $\operatorname{ctx} \mathrm{B}$ gene. The 391-bp sequence of a gene that codes for the cholera toxin B subunit was amplified by PCR. Direct use of $V$. cholerae pure culture for PCR replaces the need for DNA extraction or boiling. Increase the concentration of $\mathrm{MgCl}_{2}$ enhances the efficiency of amplification. The specificity of the assay was determined to be specific for $V$. cholerae but not for, vibrio related bacteria, E. coli, Non-Agglutinable (NAG) V. cholerae, and Aeromonas sp.
\end{abstract}

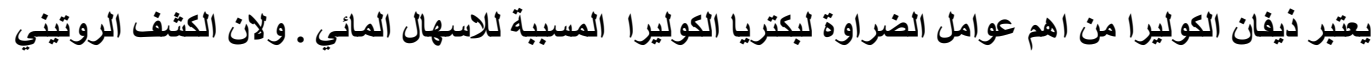

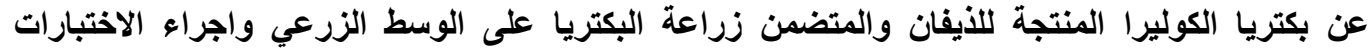

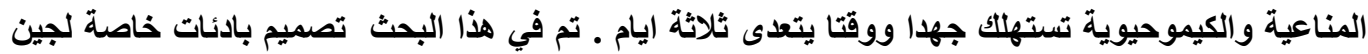
ctxB

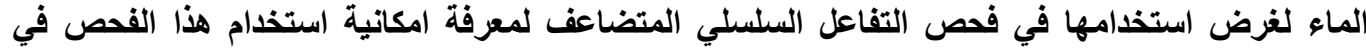
الكثف عن وجود الجين ctxB ـ وتم تضخيم تسلسل ضمن الجين المسؤول عن جزء من من الأيفان وهو بيتا

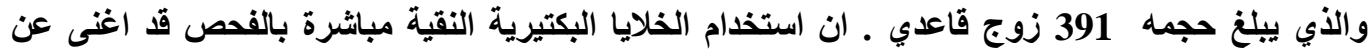

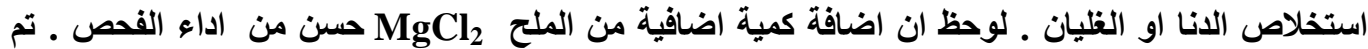

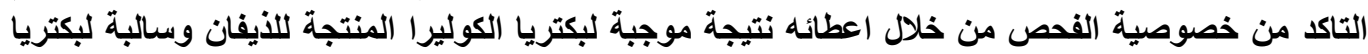

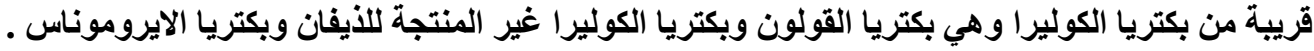

\section{Introduction}

Waterborne pathogenic microorganisms, such as those found in ground and surface waters, pose a major risk to human health. Vibrio cholerae is a well-known human pathogen causing cholera epidemics worldwide [1]. It is the causative agent of epidemics of cholera in many developing countries including Iraq. Of at least 206 known serogroups of $V$. cholerae, only two serogroups $\mathrm{O} 1$ and $\mathrm{O} 139$ strains are responsible for epidemic outbreak of cholera [1].

Rapid and accurate identification of $V$. cholerae in the potable water and aquatic environment is important for disease management and public health 
conventional culture method, which is routinely used for the isolation of $V$. cholerae, is time-consuming and may not be suitable for cells that are VBNC [2, 3]. Recent molecular techniques such as polymerase chain reaction (PCR) offer both a rapid and reliable method for detecting toxigenic $V$. cholerae occurring in the aquatic environment [4, 5].

The bacterium secretes cholera toxin that is responsible for the profuse watery diarrhea [6]. The toxin, an $85 \mathrm{kDa}$ protein, comprises of one cholera toxin A (CTA) and five B subunits (CTB) combined in an AB5 holotoxin. CTA is composed of two polypeptides $(22 \mathrm{ka}, 5 \mathrm{kD})$ responsible for the toxic activity of the toxin [7]. The B subunit pentamers $(55.6 \mathrm{kDa})$ are nontoxic and responsible for the binding of the toxin to ganglioside M1 (GM1) receptors present on the surface of intestinal epithelial cells [8]. There is a need for rapid identification of these pathogens in order to prevent disease caused by exposure to contaminated water sources. The aim of this study is to diagnose toxigenic $V$. cholera using PCR for $c t x \mathrm{~B}$ gene.

\section{Materials and methods}

Bacteria: $V$. cholerae, and other bacteria used in this study was diagnosed in the central health laboratory. $V$. cholerae cultured onto thiosulfate-citrate-bile-saltsucrose (TCBS) agar and incubated at $37^{\circ} \mathrm{C}$ for 18 to $24 \mathrm{~h}$. Other bacteria, Escherecia coli, Aeromonas sp, and NAD $V$. cholerae were cultured overnight onto nutrient agar medium at $37^{\circ} \mathrm{C}$.

PCR assays. Specific primers designed for PCR analysis of ctxB gene (Gene bank accession number AF390572) are shown in Table 1. These primers synthesized by Alpha DNA Company, Canada.

PCR reaction was conducted in $50 \mu \mathrm{l}$ of a reaction mixture containing $11 \mu 1$ suspension of few bacterial colonies, $25 \mu 1$ GoTaq ${ }^{\circledR}$ Green Master (Promega, CA), $(1.5 \mu 1) 25 \mathrm{mM} \mathrm{MgCl}_{2}, 400 \mathrm{Pmol}$ of each primer, $3 \mu \mathrm{l}$ of distilled water. Amplification was conducted using a Mastercycler (Eppendorf) programmed with 1 cycle at $95^{\circ} \mathrm{C}$ for $1 \mathrm{~min} ; 40$ cycles of $95^{\circ} \mathrm{C}$ for $1 \mathrm{~min}, 56^{\circ} \mathrm{C}$ for $1 \mathrm{~min}, 72^{\circ} \mathrm{C}$ for $1 \mathrm{~min} ; 72^{\circ} \mathrm{C}$ for $10 \mathrm{~min}$. The amplified product was subjected to $1.5 \%$ agarose gel electrophoresis, and visualized under UV (Imagemaster VDS, Pharmacia Biotech, USA) after ethidium bromide staining.

Table (1): Primers used for the amplification of $c t x B$ in toxigenic $V$. cholerae.

\begin{tabular}{cccc} 
Primers & Primer sequence $\left(5 \_-3 \_\right)$ & Nucleotide position & Amplicon size (bp) \\
Forward & TGAATTATGATTAAATTAAAATTTG & $941-967$ & 391 \\
Reverse & TTTATATCTTAATTTGCCATACTAA & $\mathbf{1 3 0 6 - 1 3 3 1}$ & \\
\hline
\end{tabular}

\section{Results and discussion}

For amplification of $c t x \mathrm{~B}$ gene, the DNA must be released from the bacterial cells by different methods, such as biochemical DNA extraction [12] and boiling for 10min [9]. In this work direct PCR for $V$. cholera was used without DNA extraction or boiling instead a pre-denaturation step was used for $5 \mathrm{~min}$ at $95^{\circ} \mathrm{C}$ [6].

In order to optimize the optimum annealing temperature a gradient PCR was used, the results showed that $55-57^{\circ} \mathrm{C}$ optimums for amplification the target sequence but with a faint band. In order to improve efficiency of PCR, 1 to $5 \mu 1 \mathrm{o}$ 
concentrations were added, in addition to the initial concentration of $\mathrm{MgCl}_{2}$, which was $1.5 \mathrm{mM} / 50 \mu 1$ reaction. A sharp band was detected on agarose gel electrophoresis with $4 \mu \mathrm{l}$ of $25 \mathrm{mM} \mathrm{MgCl} \mathrm{m}_{2}$ and specific and nonspecific bands were detected with $5 \mu \mathrm{l}$ of $25 \mathrm{mM} \mathrm{MgCl}$, Figure (1). Increasing the concentration of $\mathrm{MgCl}_{2}$ in PCR reactions tends to promote binding of primers and adding $\mathrm{MgCl}_{2}$ can prove useful in cases where no amplification products are observed. If the concentrations is too high, however nonspecific primer binding can occur resulting in amplifications that are multi-banded or smeared when visualized on an agarose gel [10].

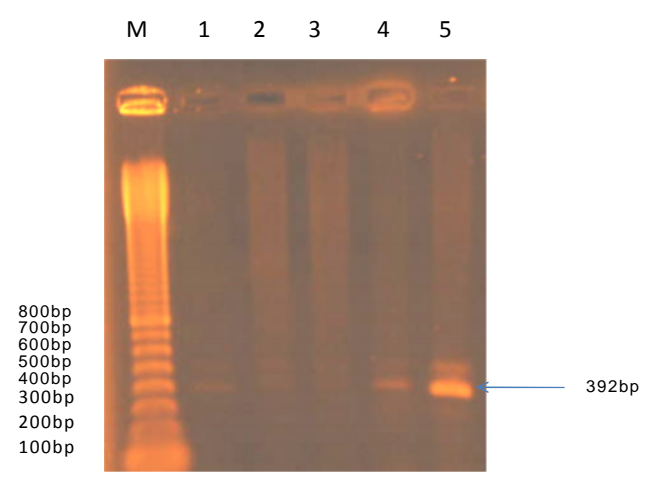

Figure 1: Agarose gel electrophoresis (1.5\%) of $\mathrm{PCR}$ reaction for ctxB gene of $V$. cholera (Inaba). M: $100 \mathrm{bp}$ DNA marker; Lane1: 1 I MgCl2; Lane2: 2 I $\mathrm{MgCl}_{2}$; Lane3: $3 \quad \mathrm{MgCl}$; Lane 4:4 I MgCl2; Lane 5:5 I MgCl2.

The specificity of PCR for toxigenic $V$. cholerae was determined by doing PCR for other related bacteria Figure (2). E coli was used because it has B subunit toxin with $80 \%$ similarity to B subunit of $V$. cholerae, non toxigenic NAG $V$. cholerae was used to differentiate toxigenic from toxigenic $V$. cholerae, Aeromonas sp. was used because it is a water borne bacteria, and produce enterotoxin and produce diarrhea as $V$. cholera[11].

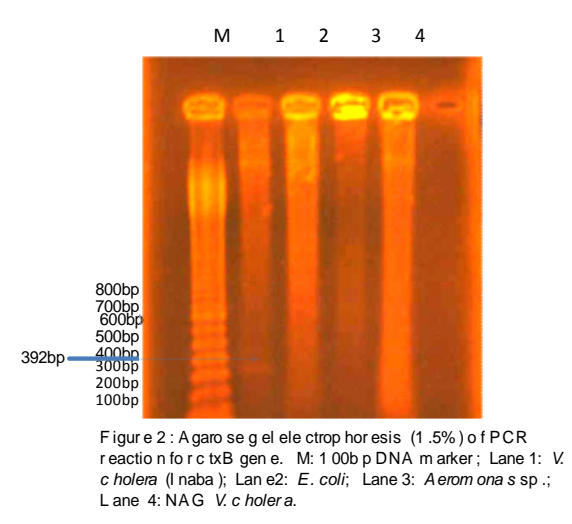


It was concluded that the specific primers in this study were specific and sensitive for detection of toxigenic $V$. cholerae from pure culture colonies using polymerase chain reaction without the need for DNA extraction. The finding of this study could be applied for testing water samples contaminated with toxigenic $V$. cholerae with high efficacy and few hours.

\section{References}

1. Alam, M., Sultana, M., Nair, G. B., Sack, R. B., Sack, D. A., Siddique, A. K., Ali, A., Huq, A., and Colwell, R. R. (2006) Toxigenic Vibrio cholerae in the aquatic environment of Mathbaria, Bangladesh. Appl. Environ. Microbiol., 72, 2849-2855.

2. Huq, A., Colwell, R. R., Chowdhury, M. A., Xu, B., Moniruzzaman, S. M., Islam, M. S., Yunus, M., and Albert, M. J. (1995) Coexistence of Vibrio cholerae O1 and O139 Bengal in plankton in Bangladesh. Lancet, 345, 1249.

3. Kapley, A. and Purohit, H. J. (2001) Detection of etiological agent for cholera by PCR protocol. Med Sci Monit., 7, 242-245.

4. Bhanumathi, R., Sabeena, F., Isac, S. R., Shukla, B. N., and Singh, D. V. (2003) Molecular characterization of Vibrio cholerae $\mathrm{O} 139$ bengal isolated from water and the aquatic plant Eichhornia crassipes in the River Ganga, Varanasi, India. Appl. Environ. Microbiol., 69, 2389-2394.

5. Chakraborty, S., Khanam, J., Takeda, Y., and Nair, G. B. (1999) Application of PCR for detection of toxigenic Vibrio cholerae O1 in water samples during an outbreak of cholera. Trans. R. Soc. Trop. Med. Hyg., 93, 527-528.

6. Singh, D.V., Isac, S.R. and Colwell, R.R. (2002) Development of a hexaplex PCR assay for rapiddetection of virulence and regulatory genes in Vibrio cholera and Vibrio mimicus. J. Clin. Microbiol. 40: 4321-4324.

7. Arzanlou. M.; Rezaee, N. ; Shahrokhi, N.; Hossini, A.; Yasuda, Y.; Tochikubo, K. [and Rezaee, M. 2005. Expression of cholera toxin B subunit in saccaromyces cervisea. Annals of microbiology, 55 (2) 145-150.

8. Vergara, M., Maestre, J., Suarez, O. and Monte, R. (1997) Toxigenic Vibrio cholera: identification of the ctxB gene. Enferm. Infecc. Microbiol. Clin. 15: 181185.

9. Hemant Kumar Khuntia, Bibhuti Bhusan Pal, and Guru Prasada ChhotrayQuadruplex. (2008), PCR for Simultaneous Detection of Serotype, Biotype, Toxigenic Potential, and Central Regulating Factor of Vibrio cholerae_JOURNAL OF CLINICAL MICROBIOLOGY, July, p. 2399-2401 Vol. 46, No. 7

10. Bonacum, J.; Stark, J. and Bonwich E. (2002). PCR methods and approaches, in Techniques in molecular systematics and evolution. Edited By Rob DeSalle, Gonzalo Giribet, Ward Wheeler,. Published by Berkhauser verlag, switzerland

11. Tereza M.; Razzolini, P.; Di Bari, M.; and Sanchez P. and Sato, M. (2008). Aeromonas detection and their toxins from drinking water from reservoirs and drinking fountains. Journal of Water and Health, 6,117-123.

12. Mousavi, S.; Nazarian, S.; Amani,J. and Karimi,A. (2008). Rapid Screening of Toxigenic Vibrio cholerae O1 Strains from South Iran by PCR-ELISA. Iranian Biomedical Journal 12 (1): 15-21. 